\title{
Penerapan teknologi tepat guna untuk unit usaha pembuatan dodol nanas di Kota Dumai
}

\author{
Wetri Febrina* dan Azmi \\ Sekolah Tinggi Teknologi Dumai \\ *wetri.febrina@gmail.com
}

\begin{abstract}
Abstrak. Nanas merupakan produk pertanian yang banyak dibudidayakan di Riau, termasuk di Kota Dumai. Kebanyakan nanas dari Dumai dijual sebagai buah segar konsumsi masyarakat lokal, karena secara demografi susah bersaing dengan nanas produksi Kabupaten Kampar yang lebih dekat dengan ibu kota provinsi, yaitu Pekanbaru. Kelebihan produksi saat panen mengakibatkan sebagian buah tidak terjual. Demikian juga kerusakan buah akibat cara panen yang salah menambah buah nanas yang tidak termanfaatkan. Hal ini mendorong masyarakat melalui unit usaha kecil, kelompok tani dan unit kegiatan masyarakat untuk mengolah buah nanas menjadi penganan seperti dodol nanas, keripik nanas, selai nanas dan lainnya. Permasalahannya terletak pada stasiun kerja yang banyak, waktu kerja yang panjang dan peralatan yang sederhana. Akibatnya keuntungan yang dihasilkan tidak sebanding dengan sumberdaya yang dikerahkan. Tujuan dari kegiatan ini adalah untuk membantu kegiatan usaha pembuatan dodol nanas dengan merancang dan membuat alat bantu produksi berupa alat pengupas nanas dan alat pengaduk dodol nanas. Metode kegiatan pengabdian ini adalah penyuluhan dan pelatihan terhadap pelaku usaha pembuatan dodol nanas, yaitu UKM Kemuning yang berlamat di Jl.Muslim No. 1 Kelurahan Mundam Kecamatan Medang Kampai, Kota Dumai. Hasil yang didapatkan dari kegiatan ini adalah peningkatan waktu kerja pembuatan dodol dari yang tadinya 3-4 hari menjadi 1-2 hari saja.
\end{abstract}

Kata kunci: alat pengaduk dodol; alat pengupas nanas; dodol nanas; nanas

\begin{abstract}
Pineapple is an agricultural product that is widely cultivated in Riau, including in Dumai. Most pineapple from Dumai was sold as fresh fruit consumed by the local citizen, because it"s demographically difficult to compete with pineapple production from Kampar which is closer to the provincial capital, Pekanbaru. The excess production at harvest results in some fruit not being sold and wasted. Likewise, fruit damage due to the wrong way in harvesting. This encourages people through farmer groups and community activity units to treat pineapple fruit into snacks such as pineapple dodol, pineapple chips, pineapple jam and others. The problem lies in many work stations, long working time and simple equipment. As a result the profits generated wasn't comparable to the resources deployed. The purpose of this activity was to assist the pineapple dodol's maker by designing and making production aids such as pineapple peeler and dodol pineapple mixer. The method of this activity was counseling and training. The object/partner in this activity was UKM Kemuning which is located at Jl.Muslim No.1 Mundam, Kecamatan Medang Kampai, Dumai. The results obtained from this activity was an increase in the working time of making dodol from previously 3-4 days to just 1-2 days.
\end{abstract}

Keywords: dodol's mixer; pineapple; pineapple dodol; pineapple peeler

To cite this article: Febrina, W., \& Azmi. 2019. Penerapan teknologi tepat guna untuk unit usaha pembuatan dodol nanas di Kota Dumai. Unri Conference Series: Community Engagement 1: 163-167.

https://doi.org/10.31258/unricsce.1.163-167

\section{(C) 2019 Authors}

Peer-review under responsibility of the organizing committee of Seminar Nasional Pemberdayaan Masyarakat 2019 


\section{PENDAHULUAN}

Kecamatan Medang Kampai adalah salah satu dari lima kecamatan yang terdapat di Kotamadya Dumai. Kecamatan ini memiliki luas wilayah $200 \mathrm{~km}^{2}$, berbatasan dengan Kecamatan Dumai Timur, Kecamatan Bukit Kapur dan Pantai Timur Sumatera. Sebagian besar wilayah kecamatan ini berupa perkebunan nanas, perkebunan sawit, lahan gambut, hutan bakau dan hutan lindung, dengan kepadatan penduduk yang masih rendah, yaitu 21,85 orang per $\mathrm{km}^{2}$. Sebagian besar penduduk Kecamatan Medang Kampai berprofesi sebagai petani, sebagian kecil lainnya adalah pedagang dan pegawai/karyawan.

Kecamatan Medang Kampai merupakan penghasil utama nanas di kota Dumai. Menurut data dari Dinas Pertanian, Perkebunan dan Kehutanan, total produksi nanas di Kecamatan Medang Kampai pada tahun 2017 adalah sebanyak 14.856,28 ton atau sekitar 80,5\% dari total produksi nanas di Dumai.

Sayangnya, sampai saat ini hasil produksi nanas masih diprioritaskan untuk memenuhi permintaan pasar domestik. Secara mutu maupun distribusi pemasaran, nanas dari kawasan ini masih kalah bersaing dengan produksi nanas dari Bangkinang, Kampar, Bengkalis dan wilayah lain di Provinsi Riau. Dari pihak petani sendiri masih kurang inisiatif untuk melakukan diversifikasi (pengolahan) produk. Hampir semua hasil produksi dijual secara mentah/ tanpa diolah dengan harga jual rata-rata Rp. 500-1.500/buah.

Pada saat terjadi over produksi harga jual nanas langsung anjlok ke titik terendah sehingga petani mendapatkan kerugian. Hal ini masih diperburuk karena kondisi jalan yang kurang bagus dan kurangnya transportasi. Pengolahan nanas menjadi penganan seperti dodol adalah sebuah solusi untuk meningkatkan tingkat pendapatan petani nanas. Dinas perindustrian Kota Dumai sudah beberapa kali melakukan edukasi dan pelatihan terhadap petani nanas melalui kelompok-kelompok tani. Namun beberapa kendala seperti kurang kontinunya kegiatan tersebut, keterbatasan dana dan masih minimnya keterampilan masyarakat menyebabkan tingkat pendapatan petani nanas masih kurang memuaskan.

Kegiatan pengabdian pada masyarakat ini bertujuan membantu petani nanas dalam usaha pembuatan dodol nanas melalui pengenalan alat bantu sehingga kegiatan membuat dodol yang tadinya lama dan tidak efisien bisa lebih cepat dan mudah..

\section{MASALAH}

Masalah yang dihadapi pembuat dodol nanas di Dumai adalah peralatan yang sederhana, pekerjaan yang melelahkan dari segi tenaga dan waktu dan pemasaran produk. Target kegiatan ini adalah mengefisienkan pekerjaan membuat dodol melalui pengenalan alat bantu berupa alat pengupas nanas dan alat pengaduk dodol.

\section{METODE}

Metode Kegiatan ini kami uraikan dalam langkah-langkah sebagai berikut :

\section{Survey dan wawancara.}

Melakukan survey ke beberapa kelompok petani nanas dan memetakan permasalahan dan kebutuhan mereka. Dari sini kami mengambil kesimpulan bahwa yang dibutuhkan petani adalah pendampingan pembuatan penganan dari dodol sehingga kelebihan produksi nanas tidak terbuang. Berikutnya kami mendatangi tempat usaha pembuatan dodol nanas dan melakukan wawancara mengenai permasalahan dan kebutuhan mereka. Dari sini kami mendapatkan bahwa permasalahan pembuat dodol nanas adalah pekerjaan yang tidak efisien sehingga membutuhkan alat bantu.

\section{Perancangan dan pembuatan alat bantu}

Yaitu berupa alat pengupas nanas dan alat pengaduk dodol. Alat pengupas nanas akan menyingkat waktu dari 3-5 menit menjadi beberapa detik saja, dan mengurangi resiko cedera terkena pisau. Alat pengaduk dodol mengurangi tenaga manusia dari 2-3 orang menjadi 1 orang saja dan waktu pengadukan dari $4-5$ jam menjadi 2-3 jam saja.

\section{Pelatihan}

Dilakukan di UKM Kemuning Kelurahan Mundam, kecamatan Medang Kampai Dumai dari Agustus-Oktober 2018 dengan 6 orang peserta. 


\section{PEMBAHASAN}

Ada dua jenis alat bantu yang dirancang untuk membantu pekerjaan pembuatan dodol nanas di UKM Kemuning, yaitu:

Alat pengaduk dodol. Berapa alat pengaduk yang dijalankan dengan motor listrik dengan dimensi panjang $120 \mathrm{~cm}$, lebar $90 \mathrm{~cm}$ dan tinggi $60 \mathrm{~cm}$. Untuk menjalankan mesin ini dibutuhkan dudukan dengan dimensi tinggi $130 \mathrm{~cm}$ dan panjang $80 \mathrm{~cm}$. Sedangkan tinggi tongkat pengaduk adalah $130 \mathrm{~cm}$ dan diameter $90 \mathrm{~cm}$. Bahan bakunya berupa pipa galvanis berdiameter 1 in untuk dudukan dan pipa stainless steel untuk pengaduk. Kecepatan putar 8-10 rpm dan menggunakan motor listrik sebagai sumber daya.

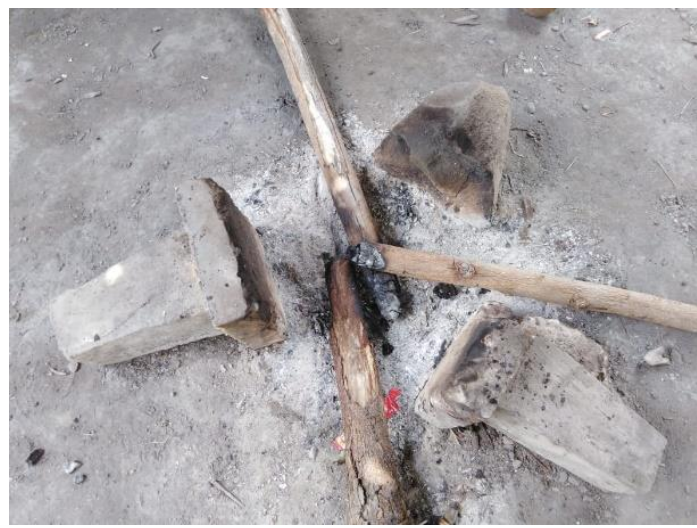

Gambar 1. Tungku kayu untuk memasak dodol

Alat pengupas nanas. Berupa pipa stainless steel sepanjang $50 \mathrm{~cm}$ yang diberi dudukan dan tuas penekan, dilengkapi mata pisau dengan diameter $16 \mathrm{~cm}$. Mata pisau dirancang untuk fleksibel supaya bisa disesuaikan dengan ukuran buah nanas yang dikupas. Tuas dijalankan secara manual dengan tenaga manusia. Waktu untuk pengupasan nanas dengan alat ini hanya dalam hitungan detik sehingga kinerjanya jauh lebih cepat dibandingkan dengan mengupas nanas secara manual.

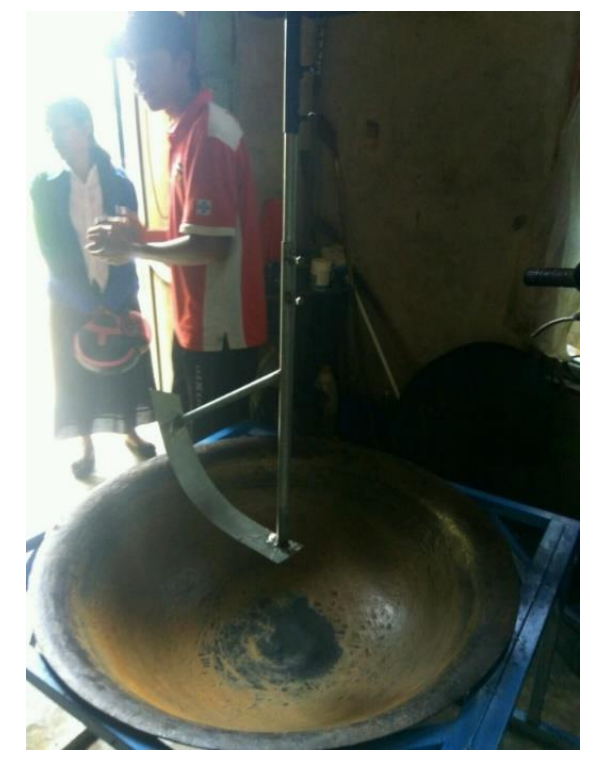

Gambar 2. Tungku dan alat pengaduk dengan bahan bakar kompor gas

Pada kegiatan ini pembuat dodol diperkenalkan dengan kedua alat bantu tersebut dan dilakukan perbandingan pekerjaaan dengan alat bantu dan tanpa alat bantu. Hasil dari perbandingan tersebut adalah:

1. Tanpa alat bantu, pekerjaan memasak dodol nanas dilakukan dengan tungku dari batu/tembok dan bahan bakar kayu. Dengan alat bantu pekerjaan memasak dodol nanas dilakukan dengan bahan bakar gas/kompor gas. Keuntungan yang didapat pembuat dodol dari penggantian bahan bakar itu adalah: a). tak ada asap dari pembakaran. b) tak repot mencari jayu bakar. c) lebih ramah lingkungan. d) masak dodol lebih merata karena panas yang dihasilkan dari gas konstan. 
2. Tanpa alat bantu diperlukan tenaga kerja 2-3 orang untuk mengaduk dodol. Dengan alat bantu tak perlu tenaga kerja buat mengaduk dodol.

3. Tanpa alat bantu diperlukan 2-5 menit untuk mengupas nanas dan membersihkan matanya. Dengan alat bantu cukup beberapa detik untuk mengupas nanas dan membersihkan matanya.

4. Tanpa alat bantu perlu 4-5 jam buat memasak dodol. Dengan alat bantu cukup 2-3 jam saja.

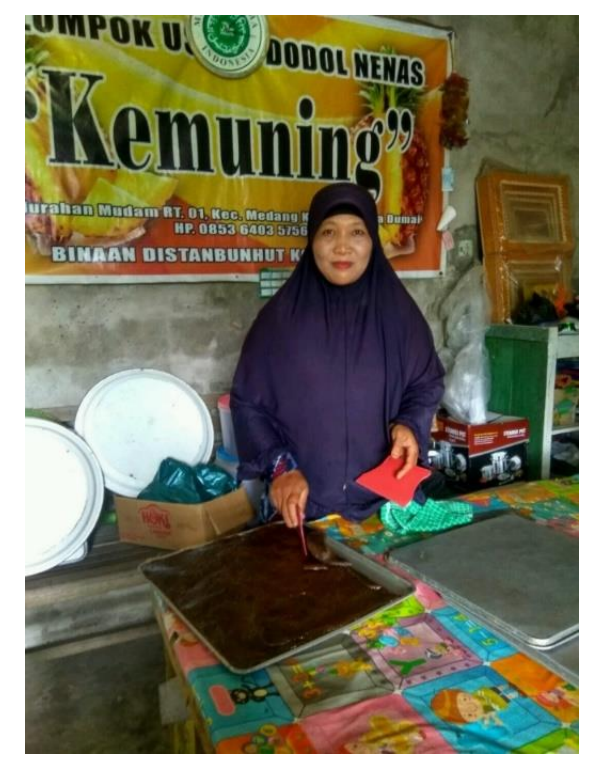

Gambar 3. Ketua UKM Kemuning, Rosnah, sedang memotong adonan dodol

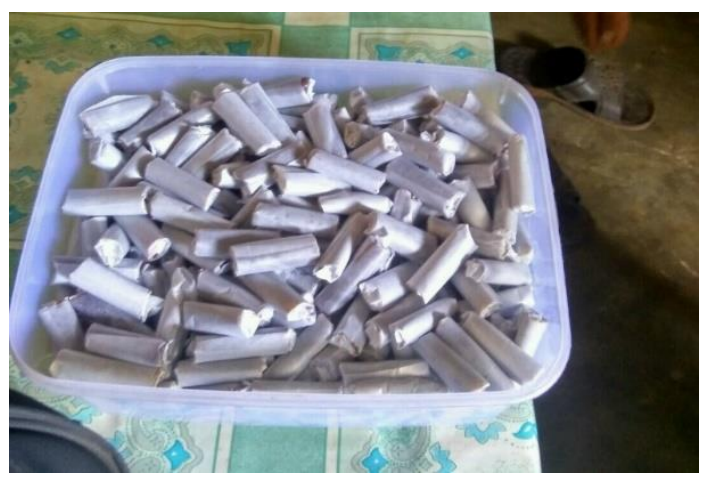

Gambar 4. Dodol yang sudah dibungkus

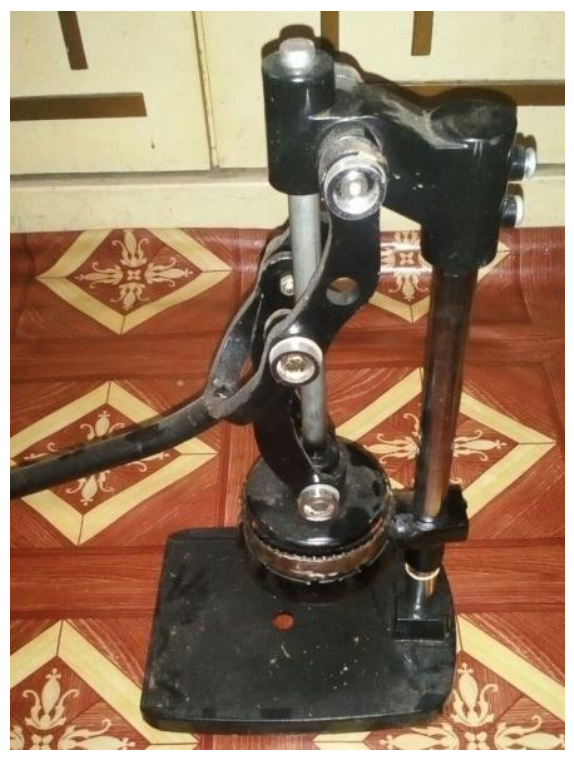

Gambar 5. Alat pengupas nanas 
Di pasaran, alat pengaduk dodol nanas yang setipe dengan yang kami buat dijual dengan harga 18-20 juta. UKM Kemuning adalah kelompok usaha kecil dengan produksi dodol 16-20 kg/minggu dengan omset dibawah 5 juta perbulan. Pembelian alat secara swadaya tidak memungkinkan karena keterbatasan dana. Karena itu bantuan alat bantu ini sangat bermanfaat bagi mereka.

Beberapa kendala yang dihadapi selama kegiatan adalah:

1. Pembuat dodol nanas rata-rata berpendidikan rendah dan gagap teknologi. Mereka antusias dan terbuka terhadap inovasi dan peralatan modern, tapi minim pengetahuan dalam penguasaan dan pemeliharaan alat. Diperlukan pendampingan berkelanjutan supaya alat bantu ini bisa dimanfaatkan dalam pekerjaan mereka.

2. Pembuat dodol nanas skala kecil/UKM rata-rata berpenghasilan kecil. Minim dana untuk pembelian dan pemeliharaan alat. Ada kekhawatiran jika alat rusak dan tidak bisa digunakan, mereka memilih kembali ke cara konvensional daripada repot-repot memperbaiki alat bantu yang diperkenalkan.

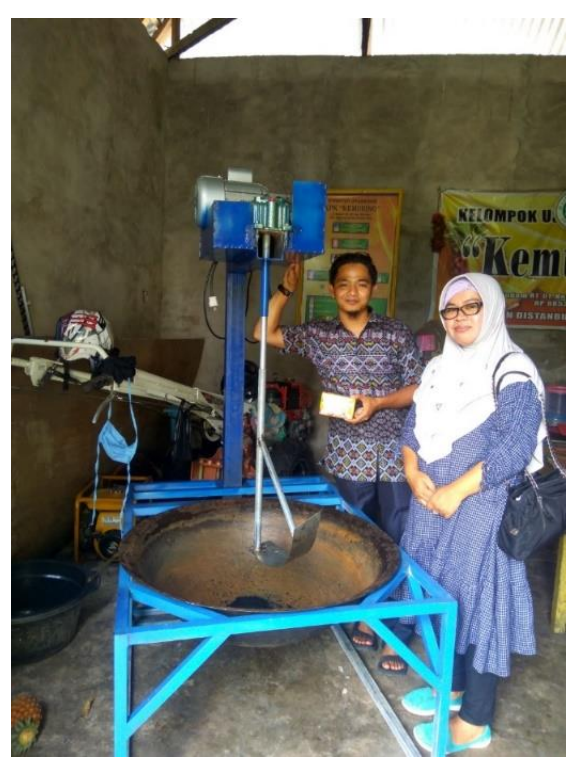

Gambar 6. Tim Penulis

\section{KESIMPULAN}

Kegiatan pengabdian masyarakat yang kami laksanakan ini cukup memenuhi target, yaitu untuk membantu pembuat dodol nanas di UKM Kemuning meningkatkan efisiensi pekerjaannaya dari segi waktu dan tenaga. Bantuan peralatan ini sesuai dengan kebutuhan mereka untuk meningkatkan produksi dengan tenaga kerja yang terbatas, Pembuatan dodol nanas yang memakan waktu lama bisa dipersingkat. Setelah penerapan teknologi alat pengaduk dodol dan pengupas nanas ini, tugas untuk kegiatan pengabdian masyarakat berikutnya adalah meningkatkan pendapatan masyarakat melalui manajemen produksi dan manajemen biaya.

\section{DAFTAR PUSTAKA}

Ariyadi, S. 2004. Teknologi Tepat Guna Pembuatan Dodol Rumput Laut. Jakarta : Kanisius

Azhary, Y. 2016. Kajian Ekonomis Aplikasi Mesin Pengaduk Pada Usaha Pembuatan Dodol (Studi Kasus: Usaha Pembuatan Dodol DI Suranadi). Doctoral dissertation, Universitas Mataram.

Dinas Pertanian, Perkebunan dan Kehutanan Kota Dumai. 2017. Total Produksi Nenas Kecamatan Medang Kampai, Dumai.

Listijorini, E., Aswata, A., \& Razib, M. 2017. Perancangan Mekanisme Alat Pengaduk Dodol Kapasitas 40 Liter. Flywheel. Jurnal Teknik Mesin Untirta, 1(1).

Tamami, Yusron, 2017. Analisa hasil pengadukan mesin pengaduk dodol dan jenang. Jurnal Rekayasa Mesin, 4(02).

Wijayanto, R, 2009. Rancangan Alternatif Pengaduk Pada Mesin Jenang Dodol Dengan Pendekatan Value Enginering (Studi Kasus Pada UD."SARI MURNI "Bono Boyolangu Tulungagung). Doctoral dissertation, Universitas Muhammadiyah Malang. 